\title{
Oroszország és a világ: IMEM0-elörejelzés 2019
}

\begin{abstract}
Az Orosz Tudományos Akadémia Primakov Világgazdasági és Nemzetközi Kapcsolatok Nemzeti Kutatóintézete (IMEMO RAN) évente elkésziti Oroszország és a világ címü elörejelzését, ${ }^{1}$ amelynek angol nyelvü összefoglalóját a prágai Nemzetközi Kapcsolatok Intézetének folyóirata, a New Perspectives adja közre. ${ }^{2}$ Jelen irásnak nem célja a tanulmány teljes körü tartalmi összefoglalása, ehelyett arra vállalkozik, hogy az elörejelzés kritikai elemzésén keresztül bemutassa, hogyan látják az orosz külpolitikai szakértők Oroszország szerepét a világban, a jelenlegi orosz-nyugati szembenállást, illetve Moszkva nemzetközi kapcsolatait.
\end{abstract}

Kulcsszavak: Oroszország, külpolitika, stratégia, NATO, Kína, Trump, Ukrajna, INF

\begin{abstract}
Jójárt Krisztián: Russia and the World: IMEMO Forecast 2019
The Primakov Institute of World Economy and International Relations of the Russian Academy of Sciences (IMEMO RAN) published its foresight study "Russia and the world", with its summary published in English in the journal New Perspectives by the Institute of International Relations of Prague. This paper does not aim to provide a complete summary of the foresight study but to review it critically and thus to offer a glimpse of how Russian foreign policy experts see Russia's role in the world, the current Russia-West conflict, and Moscow's foreign relations.
\end{abstract}

Keywords: Russia, foreign policy, strategy, NATO, China, Trump, Ukraine, INF

Az Orosz Tudományos Akadémia Primakov Világgazdasági és Nemzetközi Kapcsolatok Nemzeti Kutatóintézete (IMEMO RAN) Oroszország egyik legnagyobb presztízsü, világviszonylatban is tekintélyesnek számító kutatóintézete. Az intézmény mintegy 318, túlnyomó többségében tudományos fokozattal rendelkező kutatót foglalkoztat. ${ }^{3}$ Az 1950-1960as években egy sor, adott földrajzi régióra vagy országra fókuszáló intézetet hoztak létre az Orosz Tudományos Akadémia berkein belül annak érdekében, hogy pótolják az állami bürokrácia ismerethiányát ezen a téren. ${ }^{4}$ Ebbe a folyamatba illeszkedett az IMEMO újraalapítása is 1956-ban az 1925 és 1948 között múködő Világgazdasági és Nemzetközi Kapcsolatok Intézete jogutódjaként. ${ }^{5} \mathrm{Az}$ intézet később az USA- és Kanada-tanulmányok Intézet mellett a szovjet korszak legismertebb kutatóközpontjává vált, és jelentős szerepet

\footnotetext{
А. А. Дынкин - В. Г. Барановский: Россия и мир: 2019, [online], 2018 Forrás: imemo.ru [2019. 10. 24.]

I. KobrinskaYa - G. MachaVARIAny (szerk.): IMEMO Forecast - Russia and the World 2019, [online] New Perspectives, 27. évf. 2019/2, 1-29. o.

History of IMEMO, [online], Forrás: www.imemo.ru [2019. 10. 24.]

4 Anton Barbashin - Alexander Graef: Thinking Foreign Policy in Russia: Think Tanks and Grand Narratives, [online], 2019. 11. 12., 7. o. Forrás: Atlantic Council [2019. 10. 24.]

History of IMEMO: $i . m$.
} 
vállalt a gorbacsovi glasznoszty- és peresztrojka-időszak politikai és gazdasági reformjainak előkészítésében. ${ }^{6}$

Az IMEMO 17. éve készíti el Oroszország és a világ című előrejelzését, amely egy gazdasági és külpolitikai részből áll. Az előrejelzés legfőbb célja mindazon tényezők számbavétele és elemzése, amelyek hatással vannak Oroszország stabil gazdasági fejlődésére rövid távon. Emellett az IMEMO stratégiai előrejelzéseket is készít, amelyek húszéves periódusra kitekintve veszik górcső alá azokat a várható világgazdasági és világpolitikai trendeket, amelyek hosszú távon határozzák majd meg a nemzetközi rendszert és benne Oroszország helyét. ${ }^{7}$ A stratégiai előrejelzésekkel szemben a Kutatóintézet éves előrejelzései az aktuális nemzetközi folyamatokból indulnak ki, és számba veszik mindazon tényezőket, amelyek pozitívan vagy negatívan befolyásolhatják e folyamatokat az elkövetkező évben. Így például - ellentétben a stratégiai előrejelzés műfajával, amely a strukturális tényezőkre fókuszál - szerepet kap az elemzésben a meghatározó politikai vezetők személye, vagy az éppen soron következő parlamenti és elnökválasztás kimenetelének latolgatása is mint a nemzetközi trendek alakulását befolyásoló tényezők. Másrészről elöfordulnak olyan - sokszor váratlan - politikai vagy gazdasági események, amelyek ugyan rövid távon nem feltétlen járnak érdemi következménnyel, közép- és hosszú távon azonban önmagukban is nemzetközi folyamatok elindítói lehetnek. A 2019-re vonatkozó előrejelzés ilyen eseményként tekint az INF-szerződés amerikai részről történő egyoldalú felmondására. Az IMEMO Oroszország és a világ címü kiadványai 2015 óta rövidített változatban, angol nyelven is elérhetők. A 25-30 oldalas angol nyelvü összegzést a prágai Nemzetközi Kapcsolatok Intézetének folyóirata, a New Perspectives adja közre azzal a céllal, hogy bepillantást engedjen az orosz külpolitikai szakértői elit világnézetébe. Az előrejelzés publikálását követő számban a folyóirat teret enged az elemzéshez füzött szakértői kommentároknak is.

Jelen írásnak nem célja a tanulmány teljes körü tartalmi összefoglalása. Helyette arra vállalkozik, hogy az előrejelzés kritikai elemzésén keresztül bemutassa, hogyan látják az orosz külpolitikai szakértők Oroszország szerepét a világban, a jelenlegi orosz-nyugati szembenállást, illetve Moszkva nemzetközi kapcsolatait. Az elemzés különös hangsúlyt fektet az elörejelzés azon tételeinek tartalmi kifejtésére, amelyek ellentmondanak a hivatalos orosz narratívának vagy megkérdőjelezik a Kreml külpolitikáját. Az írás a New Perspectives-ben megjelent összefoglalót dolgozza fel az eredeti orosz nyelvü kiadvány figyelembevétele mellett.

\section{Az elörejelzés felépítése}

Az eredeti, mintegy 170 oldalas elörejelzés két fő részből áll: gazdaság és külpolitika. Míg a gazdaság kérdése valamivel nagyobb fókuszt kap az eredetiben, addig az angol nyelvü verzióban egyértelmüen a külpolitikai elem dominál, ami megfelel a New Perspectives külpolitikai fókuszának. ${ }^{8} \mathrm{Az}$ általános geopolitikai helyzetkép és trendek bemutatását követően az összefoglaló három fö földrajzi és politikai vektor mentén vázolja fel részleteiben

\footnotetext{
BARBASHin-Graef: $i$. m., 41.

Az IMEMO 2011-es, 2030-ig kitekintő stratégiai előrejelzése intézetünk Védelmi Tanulmányok kötetében fog megjelenni.

8 A 26 oldalas törzsanyagban mindössze 3 oldal foglalkozik a gazdaság kérdéskörével.
} 
a közeljövőben meghatározó tényezőket. A Nyugat (az Amerikai Egyesült Államok [a továbbiakban: Egyesült Államok] és az Európai Unió) mind az eredetiben, mind az angol nyelvű változatban az első helyen szerepel. Érdekesség azonban, hogy míg utóbbiban a második helyen az ázsiai és csendes-óceáni térség szerepel, addig az eredeti tanulmányban ezt a régiót az utolsó helyen, a posztszovjet térség és a közel-keleti helyzet taglalását követően mutatják be.

\section{Objektívnek tekinthető-e az elörejelzés? A tanulmány nyelvezete}

A tanulmány alapvető célja, hogy hiteles előrejelzést adjon az orosz politikai, gazdasági és szakértői elit számára a világgazdasági és külpolitikai folyamatok alakulásáról. Tartalma megerősíti, hogy valóban objektív, tudományos igényü munkáról beszélhetünk. A szakértők által leírt megállapítások nemcsak hogy olykor éles kontrasztot mutatnak az orosz propagandával, de számos esetben kifejezetten ellentmondanak a Kreml deklarált külpolitikai irányvonalának. (Ezeket az adott tartalmi részek feldolgozásánál jelezni is fogom.) Jelen alfejezet a továbbiakban csupán azon kifejezések vizsgálatával foglalkozik, amelyek önmagukban is árulkodók a szerzők világnézetéről és politikai beállítottságáról, illetve a tanulmány céljával kapcsolatosan.

A tanulmány angol nyelvü verziójának szóhasználata kifejezetten arra utal, hogy a szerzők mindenképp el akarták kerülni még az elfogultság látszatát is. Így az előrejelzés következetesen „ukrajnai” (Ukraine), nem pedig a Kreml-párti médiában megszokott „ukrán” (Ukrainian) válságról beszél. Ez szemantikai kérdésnek tünhet csupán, ám tartalmi szempontból igen lényeges, hogy az „ukrán válság” formula azt sugallja, hogy az egy ukránok közötti belső konfliktus, miközben valójában egy orosz-ukrán háborúról beszélhetünk. Szintén fontos kiemelni, hogy az elemzés Kijev angol átírásában az ukrán kiejtést (Kyiv) követi. Ez azért is figyelemreméltó, mert az Egyesült Államok Földrajzi Nevek Tanácsa (Council of Geographic Names Authorities [CoGNA]) csak 2019 júniusában váltotta fel az addig hivatalos és (oroszos) Kievet Kyivvel, a korábbi írásmód pedig gyakran visszaköszön még vezető angol nyelvű újságok cikkeiben is. Megjegyzendő, hogy a fentiek az előrejelzés orosz nyelvü változatában nem érhetők tetten. ${ }^{9}$ Mindkét nyelvü verzióban fontosnak tartották ugyanakkor a kutatók a VCIOM közvéleménykutatót ${ }^{10}$ a „Kremlhez lojális” jelzővel illetni, amely szintén az objektív tájékoztatás szándékát jelzi. ${ }^{11}$

\footnotetext{
9 A szerzők az ukrainszkij krizisz (украинский кризис) kifejezést használják, szemben a nem Kreml-párti nyelvhasználatban preferált krizisz v Ukrainye (кризис в Украине), vagyis „válság Ukrajnában” jelző helyett. Szintén megjegyzendő, hogy az „Ukrajnában” kifejezésre az avíttnak számító „Ha” (-on, -en, -ön) elöljárót használja az elemzés a „, (-ban, -ben) helyett. Ennek jelentősége abban áll, hogy előbbi Ukrajna függetlensége előtt volt használatos, ám a Kreml-párti nyelvhasználatban továbbra is ez a formula a bevett, mintegy nyelvileg is degradálva ezzel a független Ukrajnát. Érdekes, hogy az előrejelzés kilenc esetből kétszer mégis a „ڤ” elöljárót használja. A „Ha” elöljáró használatának egyébként a „the Ukraine” tulajdonnév feleltethető meg az angol nyelvben, amely az ország függetlensége óta szintén archaikusnak számít, és ma már a „the” nélküli alak a hivatalosan elfogadott. Szemben az orosz változattal, az előrejelzés angol összegzése az új írásmódot követi.

10 Az Összoroszországi Társadalmi Véleményt Kutató Központ (VCIOM) a legrégebb óta működő ilyen intézmény Oroszországban. A VCIOM központ honlapja, [online], 2019. 10. 24. Forrás: vciom.ru [2019. 10. 24.]

11 Дынкин-Барановский: i. m., 91.
} 


\section{Rendszertelenség, erő, ellenállás}

Ezzel a három szóval jellemzik az IMEMO szakértői a jelenlegi nemzetközi rendszer dinamikáját. Úgy látják, hogy egyrészt a világ egyre távolodik a második világháború utáni nemzetközi rendszer szabályaitól, alapelveitől és értékeitől (rendszertelenség), másrészt pedig jelentős számú világhatalom próbál ellenállni Oroszország azon kitartó törekvésének, hogy visszaszerezze elvesztett világhatalmi pozícióját (erő és ellenállás). Ez utóbbi tekintetében a szakértők azt írják, hogy a világ elismeri Oroszország természetes jogát ahhoz, hogy erősítse globális pozícióját, ugyanakkor ennek megvalósítását bizalmatlanság és ellenállás kíséri. Az elemzés nem részletezi, hogy melyik országnak mekkora szerepe volt vagy van a világháború utáni nemzetközi rend lebontásában, ahogy azt sem taglalja, hogy Moszkva törekvése a világhatalmi státusz visszaszerzésére miként vezetett háborúhoz Grúziában vagy Ukrajnában. Ugyanakkor felveti annak problémáját, hogy az orosz külpolitikát növekvő mértékben határozzák meg belpolitikai és társadalmi-gazdasági tényezők. Itt a szerzők minden bizonnyal arra utalnak, hogy a társadalmi jóléten alapuló legitimáció kifulladásával a Kreml egyre inkább külpolitikai sikerek elérésével próbálja megtartani a társadalom támogatását. Összességében mindezen tényezők három fö trendet eredményeznek az orosz szakértők szerint: Oroszországnak a Nyugattal fennálló kapcsolatainak instabillá válását, a Kínával való kapcsolatok megerősödését, valamint elmélyülő válságot a nemzetközi viszonyrendszer egészében.

Az IMEMO szakértői megjegyzik, hogy a nemzetközi rendszer erodálódása Donald Trump megválasztásával immáron földcsuszamlásszerü és látszólag visszafordíthatatlan folyamattá vált. Az új amerikai elnök lépései saját szövetségeseit is megosztják. A védelmi kérdések „pénzügyiesítése” azt eredményezte, hogy az európai politikusok számára az egyik elsőszámú prioritás az EU stratégiai autonómiájának elérése lett, beleértve a PESCO (Permanent Structured Cooperation - állandó strukturált együttmúködés) program megvalósítását. Másutt az elemzés azonban kiemeli, hogy a korlátozott erőforrások miatt minden bizonnyal a NATO-val és az Egyesült Államokkal való bilaterális együttmüködés erösödése várható az EU-védelempolitika kárára. Miközben a Kínával szemben vívott kereskedelmi háborút, az Iránnal való megállapodást és a rövid és közepes hatótávolságú, szárazföldi rakéták betiltásáról szóló INF-szerződés felbontását egyértelmüen kihívásként értékelik, addig az orosz elemzők lehetőséget is látnak a nemzetközi helyzet válságában és instabilitásában. Ez ugyanis lehetőséget ad Moszkva számára arra, hogy megszilárdítsa pozícióját mint vezető és pragmatikus (!) globális játékos, aki számos nemzetközi szereplő számára partner lehet. Ugyanakkor az instabilitásból fakadó kockázatok minden bizonnyal felülírják a lehetséges hasznot. Mint megjegyzik, a növekvő zavar és káosz kockázatot jelent az erejét fitogtató és vele szemben ellenálló szereplőknek egyaránt. Ebben a kontextusban a fegyverzetkorlátozást a legsürgetőbb kérdésként értékeli az elemzés.

\section{Az INF-szerződés felmondása - egy veszélyes precedens}

Miközben az 1987-ben a Szovjetunió és az Egyesült Államok között megkötött megállapodás amerikai részről történő egyoldalú felmondását komoly kockázatként értékelik 
az IMEMO szakértői, annak rövidtávú várható következményeivel kapcsolatosan józan és mérsékelt előrejelzést adnak. A szerződés felmondása ugyanis szerintük nem fog szükségszerűen fegyverkezési versenyhez vezetni. Az elkövetkező néhány évre átmeneti állapotot jósolnak, amelyben sem szabályozás nem lesz érvényben, sem pedig fegyverkezési verseny nem várható. Az elemzés még középtávon sem valószínűsíti, hogy Washington rakétákat telepítene Európába vagy Északkelet-Ázsiába. Ugyanakkor azt igen, hogy folytatódni fog az amerikai kongresszus által jóváhagyott kutatás-fejlesztési program, amely 500 kilométer feletti hatótávolságú, nem nukleáris töltetű cirkálórakéták indítására képes mobil kilövőegységek kifejlesztését célozza. Az elörejelzés szerint ugyanakkor nem zárható ki a politikai megoldás sem, amely a gyakorlatban egy háromoldalú, Kínát is magában foglaló szerződés aláírását jelentené. Az elemzés ezzel utal arra, hogy a fő motiváció az amerikai kilépés mögött minden bizonnyal a Kína által birtokolt és az amerikai-szovjet kétoldalú szerződés tilalma alá tartozó rakéták ténye volt. Az elemzés szintén optimista az esedékes, 2026-ig szóló, hadászati fegyvereket korlátozó új START-szerződés aláíásával kapcsolatosan, amelynek lehetőségét a 2018-as amerikai nukleáris stratégia (U.S. Nuclear Posture Review) sem zárja ki. Ugyanakkor amennyiben ez nem történik meg 2019-ben, az amerikai elnökválasztás miatt erre kevés esély lesz 2020-ban. Ennek ellenére is, ha nem lesz új START-megállapodás, az valószínüleg hosszú távon sem vezet majd fegyverkezési versenyhez. A jelenlegi modernizációs tervek egyik oldalon sem mutatnak túl a START által meghatározott számokon. Ezért a valódi veszély nem a modernizációs törekvésekben, hanem az átláthatóság hiányában rejlik. Az előrejelzés ugyan máshol tesz említést erről, logikailag azonban ehhez kapcsolódik Vlagyimir Putyin 2018-as beszéde, amelynek jelentős része az új, nukleáris szuperfegyverek fejlesztéséről szólt. Az IMEMO szakértői szerint ennek egyik célja az volt, hogy párbeszédre és a fegyverzetkorlátozásról szóló tárgyalásokra kényszerítse az Egyesült Államokat. Ennek megemlítése azért fontos, mert miközben más orosz szakértők is rámutattak arra, hogy Putyin szándéka valójában a tárgyalások kikényszerítése volt, a beszéd ezen olvasata hiányzott a nyugati szakértői véleményekből, amelyek az - egyébként tagadhatatlanul - fenyegető hangvételt és belpolitikai dimenziót emelték ki. ${ }^{12}$

\section{Az orosz befolyás, szankciók, a Nyugattal fennálló kapcsolatok jövője}

Érdekes része az elemzésnek az orosz befolyás kérdéskörének taglalása. Az elemzés ugyan következetesen használja az „állítólagos” vagy más jelzőt az orosz beavatkozási kísérletek példáit említve, az orosz befolyásolási törekvések tényét azonban implicit módon elismeri. Ezzel kapcsolatban egyrészt rámutat arra, hogy számos nyugati szakértő is úgy véli, hogy Oroszország csak kihasználja, nem pedig előidézi azokat a problémákat, amelyek

12 Egy orosz szakértő, Andrej Baklickij egy 2018 júniusában Washingtonban szervezett előadáson elmondta, hogy bizonyos forrásoktól tudja, hogy a beszéd eredeti szándéka egy meghívás volt tárgyalások folytatására. Baklickij mindezt annak újabb bizonyítékaként emelte ki, hogy mennyire tévesen értelmezi az amerikai és orosz fél egymás üzeneteit és jelzéseit. A beszélgetés az alábbi linken tekinthető meg: U.S. - Russia Crisis Stability: Results from a Strategic Dialogue, [online], 2018. 06. 13. Forrás: csis.org [2019. 10. 24.] 
kialakulásáért maguk a nyugati társadalmak a felelösek. Másrészt kifejti, hogy az orosz politikai rendszer egyáltalán nem homogén, az számos érdekcsoportból áll, amelyek eltérő véleménnyel bírnak Oroszország fejlődésére és nemzetközi szerepére vonatkozóan, és amelyek közül számos egyáltalán nem támogatja az európai szélsőjobbal való barátkozás politikáját. Harmadrészt megjegyzi, hogy Oroszország aligha egyedülálló abban, hogy befolyásolási politikát folytat, minthogy Kína, Törökország, Szaúd-Arábia és Katar egyaránt hasonló gyakorlatot követ.

Míg a nyugati szankciók hatását rendre alulértékeli az orosz propaganda, az IMEMO szakértői több helyen is kiemelten foglalkoznak azzal. Mint megjegyzik, az orosz gazdaság kilátásaival kapcsolatos bizonytalanság legfőbb forrása a globális exportpiacok helyzete mellett a Moszkva elleni szankciók és korlátozások. Külön kiemelik a Szkripal-ügy kapcsán elfogadott amerikai szankciókat, amelyek bevezetése a tanulmány írásának időpontjában még nem történt meg. ${ }^{13} \mathrm{~A}$ tanulmány szerzői szerint az orosz gazdaságdiplomácia egyik fó feladata 2019-ben is a szankciós rezsim gyengítése marad. Ugyanakkor ennek elérésére kevés esély mutatkozik: az EU-s szankciók ugyanis a kelet-ukrajnai konfliktus dinamikájához kötöttek, ezzel kapcsolatban pedig az ukrán elnök- és parlamenti választás évében nem várható előrelépés. Másrészről pedig mindazon EU-tagállamoknak, amelyek ellenzik a szankciót, nincs okuk kezdeményezőként fellépni a szankciós nyomás enyhítése érdekében.

Az elemzés úgy látja, hogy Ukrajna kérdése kulcsfontosságú marad a Nyugattal fennálló kapcsolatok normalizálása szempontjából. Amennyiben rövid időn belül nem tesznek az ukrajnai helyzet rendezésének irányába mutató gesztust, úgy csökkeni fog annak esélye, hogy megállapodásra jussanak a kiberbiztonság, a fekete- és balti-tengeri katonai tevékenységekből eredő kockázatok csökkentése vagy a fegyverzetkorlátozás kérdésköreiben. Mindez arra utal, hogy az orosz szakértők szerint a Nyugattal való kapcsolat tartósan konfliktusos marad, ezért a legtöbb, ami elvárható, hogy olyan megállapodásokat hozzanak tető alá, amelyek stabil keretrendszerét adják a vetélkedésnek, és általuk elkerülhető a nem szándékos konfrontáció. Ennek veszélye különösen a már említett balti- és fekete-tengeri térségben áll fenn. Az elemzők szerint nem lehet kizárni annak lehetőségét, hogy bilaterális alapon további amerikai erőket telepítenek a Baltikumba.

Ugyanakkor az előrejelzés arra is rámutat, hogy a Nyugat-ellenességnek és az agreszszív orosz külpolitikának nincs meg a társadalmi támogatottsága. A külpolitikai sikerek, mindenekelőtt a Krím Oroszországhoz csatolása kapcsán meglévő társadalmi konszenzus fokozatosan elveszíti mobilizációs és legitimációs erejét. A Nyugat-ellenes retorika szintén veszített támogatottságából. A Levada felmérései szerint a társadalom 42\%-a látja pozitívan az Egyesült Államokat a korábbi 20\%-hoz képest, míg azok aránya, akik negatívan ítélik meg, 40\%-ra csökkent. Egy másik, szintén a Levada által végzett felmérés szerint 2018 végén a válaszadók mintegy 70\%-a gondolta úgy, hogy a Nyugattal való konfrontatív kapcsolatot a normalizáció irányába kell terelni.

13 Az azóta életbe léptetett szankciók az amerikai bankok számára tiltják a kölcsön vagy hitel nyújtását orosz bankoknak, illetve automatikusan ellenzik a nemzetközi pénzügyi szervezetek által folyósított hitel, pénzügyi vagy technikai segítség meghosszabbítását Oroszország számára. Skripal case: US slaps new sanctions on Russia, [online], 2019. 08. 02. Forrás: bbc.com [2019. 10. 24.] 


\section{A Trump-tényező}

Mivel a Vlagyimir Putyin felé mutatott személyes szimpátia miatt az orosz politikai elit egy része - legalábbis kezdetben - pozitív várakozásokkal tekintett Donald Trump elnökségére, érdemes kitérni arra, hogy az IMEMO szakértői hogyan értékelik Trump elnökségét az orosz érdekek szempontjából. ${ }^{14} \mathrm{Az}$ elemzés egyértelmüen negatívan vonja meg a Trumpadminisztráció mérlegét, noha ez csak részben áll közvetlen összefüggésben a végrehajtói hatalmi ág tevékenységével. Közvetlenül Trump kijelentéseinek köszönhető, hogy az amerikai külpolitika kiszámíthatatlanná vált nemcsak Oroszország felé, hanem annak partnerei (különösen Kína) és az olyan régiók vonatkozásában is, ahol Moszkva aktívan van jelen (legfőképp a Közel-Kelet). Minél inkább korlátok közé szorul az amerikai elnök lehetőségeit tekintve az olyan kampányígéretek teljesítésében, mint a mexikói határon építendő fal, Trump annál harcosabb álláspontot fog felvenni Kínával szemben, hogy megpróbáljon sikert felmutatni egy másik választási ígéretével kapcsolatban. Az elemzés ugyanakkor azt is megjegyzi, hogy Trump kiszámíthatatlan retorikája és ellentmondásos kijelentései ellenére az általa vezetett adminisztráció továbbra is a Nemzeti Biztonsági Stratégiában lefektetett szempontokkal összhangban fogja alakítani az amerikai külpolitikát.

Oroszország szempontjából sokkal inkább meghatározók azok a tényezők, amelyek Trump kijelentéseivel és döntéseivel csak közvetett módon kapcsolhatók össze. Ilyen az a tény, hogy a Demokrata Párt kezében az „orosz kártya” vált a fő nyomásgyakorlási eszközzé az elnökkel szemben, amelyet az elemzők szerint újult lendülettel fognak kijátszani a jövőben. Mindeközben a megosztott Kongresszusban az Oroszország-politika sajátos közös nevezővé vált. Mindez, valamint az, hogy Oroszország a politikai elitek játszmáiban egyfajta alkualapot képez, az amerikai szankciós politika erősödéséhez vezet majd az előrejelzés szerint.

\section{Kína}

A virágzó orosz-kínai kapcsolatok ellenére az elemzés rendkívül hideg fejjel tekint Kínára és a Moszkva-Peking kapcsolatok potenciáljára. Noha az Egyesült Âllamokkal fennálló gazdasági és kereskedelmi feszültségek Kínát egyre inkább az Oroszországgal kialakítandó szorosabb politikai, gazdasági és katonai együttműködés irányába terelik, ez a gyakorlatban valószínűleg korlátozott marad. Az amerikai másodlagos szankcióktól való félelem ugyanis szükségszerüen óvatosságra inti a kínai gazdasági szereplőket az orosz cégekkel és személyekkel való együttmüködés tekintetében. Miközben az elemzők sokszor felvetik Trump kiszámíthatatlanságát és ellentmondásos retorikáját, az amerikai elnök Kínával kapcsolatos kifogásait jogosnak és konzekvensnek tekintik. Úgy fogalmaznak, hogy tekintettel arra, hogy az Egyesült Államoknak az áruforgalom viszonylatában szinte valamennyi országgal

14 Egyes orosz szakértők még mindig úgy vélik, hogy Trump elnöksége kedvező a Kreml szempontjából. Dmitrij Trenyin, a Carnegie Moscow Center igazgatója szerint Putyin továbbra is pozitívan tekint Trump elnökségére: nem amiatt, mert az amerikai Oroszország-politika radikális megváltozásában reménykedik, hanem azért, mert Trump a liberális univerzalizmust a nagyhatalmi politikával váltja fel, amely - szemben az értékalapú külpolitikával - lehetőséget ad a kompromisszumra. Dmitri Trenin: Why Putin Isn’t Sweating the Midterms, [online], 2018. 11. 06. Forrás: Politico.com [2019. 10. 24.] 
szemben negatív a külkereskedelmi egyenlege, ez elöbb vagy utóbb mindenképp lépésre késztette volna a mindenkori amerikai vezetést. Washington valóban betartott minden WTO-elöírást a kereskedelmi korlátok lebontásában, aminek eredményeként az amerikai importvámok ugyanazon termékre sokszorosan alacsonyabbak, mint a kereskedelmi partnerei esetében. A szellemi tulajdonjogok Kína általi figyelmen kívül hagyása szintén jogos vitapont. Amerikai számítások szerint az, hogy Kína ingyen használja az amerikai szellemi tulajdont, évente 600 milliárd dollár kárt okoz az Egyesült Államok számára. Az IMEMO értékelése Putyin elnöknek a témában tett megszólalásaival erős kontrasztot mutat. Az orosz elnök 2019 júniusában egy szentpétervári gazdasági fórumon „mértéktelen gazdasági egoizmussal" vádolta az Egyesült Államokat a Kínával szemben tett lépései okán. ${ }^{15}$

A Trump elnök által Kína ellen bevezetett korlátozások rámutattak a kínai hightech szektor sebezhetőségére és külföldi beszállítóktól való függőségére. Az orosz elemzők szerint Peking elsődleges célja mindenképp az lesz, hogy kompromisszumra jusson Washingtonnal a kereskedelmi vita kérdésében. Emellett a kínai vezetés célja, hogy diverzifikálja exportpiacait és folytassa az Egy övezet, egy út kezdeményezés (Belt and Road Initiative) megvalósítását, amely a kínai gazdasági expanzió elsődleges eszköze. Ez utóbbi azonban az IMEMO szakértői szerint egyre nagyobb ellenálásba fog ütközni abbéli félelmek miatt, hogy a kínai cégek megszerzik a nemzeti infrastruktúra feletti ellenőrzést, valamint hogy a projektekkel párhuzamosan Peking katonai jelenlétét is növeli. Másrészről a fogadó országok nemzeti gazdasági és ipari stratégiái gyakran nem összeegyeztethetők a kínai célokkal.

\section{Ukrajna}

Ukrajnának központi szerepe van mind az Oroszország elleni szankciók, mind pedig általában az orosz-nyugati politikai és gazdasági kapcsolatok szempontjából. Az előrejelzés szerint, noha az Északi Áramlat 2 és a Török Áramlat gázvezetékek elkészülte csökkenti majd Ukrajna tranzitszerepét, a Kijevvel való megállapodást az Északi Áramlat 2 előfeltételének tekinti. E nélkül a projekt megvalósítása veszélybe kerülhet, amelynek elhalasztását egyébként sem zárják ki a szakértők. Az előrejelzés 2018 év végi publikálása, illetve az angol nyelvü összefoglaló 2019. nyári megjelenése közötti időszakban számos olyan esemény következett be, amely szükségessé tette ezek feldolgozását, illetve az önreflexiót az elemzők részéről. Kétségkívül a legváratlanabb és legnagyobb hatású esemény Zelenszkij megválasztása volt, aminek bekövetkeztét - ahogy a szerzők megjegyzik - senki sem látta elöre sem Kijevben, sem pedig Moszkvában. Ez a fejlemény jelentős módon átértékelte az IMEMO 2018-as (tehát az ukrán elnökválasztási előtti) álláspontját az orosz-ukrán kapcsolatok alakulását illetően, amely meglehetősen borús jövőt vázolt fel. Az angol nyelvű összefoglaló már mérsékelten pozitív várakozásokkal tekint a Zelenszkij vezette Ukrajna és Oroszország közötti viszonyra. A választás az orosz szakértők szerint cáfolta a közkeletű tézist Ukrajna kettészakadásáról, és rávilágított arra, hogy a társadalom belefáradt a háborúba és a korrupcióba. Zelenszkij nem fog letérni az EU-párti külpolitikai pályáról, ugyanakkor lépése-

15 Andrey Ostroukh - Katya Golubkova: Putin stands by China, criticizes U.S., in trade, Huawei disputes, [online], 2019. 06. 07. Forrás: Reuters.com [2019. 10. 24.] 
ket fog tenni a kelet-ukrajnai helyzet megoldása érdekében. Az elemzők szerint arra is van esély, hogy Zelenszkij igyekszik majd elősegíteni az Oroszországgal fennálló kapcsolatok normalizálását. Mindez jelentős különbség a 2018-ban jósoltakhoz képest, amely meglehetősen pesszimista/realista módon értékelte Moszkva és Kijev várható kapcsolatát a 2019-es évben. Ugyanakkor Moszkva számára kihívást jelent megkülönböztetni Zelenszkij átgondolt és valódi jelzéseit a „hamis üzenetektől”. Az előrejelzés szintén kiemeli a társadalmi hangulat változását mind Oroszországban, mind pedig Ukrajnában. Nagyjából az oroszok 33\%-a látja Ukrajnát pozitívan, míg ez az arány nagyjából megegyezik az ukrán oldalon, azaz körülbelül ugyanekkora százalékban ítélik meg Oroszországot pozitívan Ukrajnában.

\section{Összegzés}

Kijelenthető, hogy az IMEMO előrejelzése objektív képet ad a várható kilátásokról a közeljövőre vonatkozóan, elsősorban orosz nézőpontból és az Oroszország szempontjából fontos fejlemények tárgyában. A szakértők az orosz-nyugati kapcsolatok válságát rendszerszintűnek látják, ami Moszkva újbóli felemelkedésének és a Nyugat ezzel kapcsolatos bizalmatlanságának és ellenállásának következménye. Az elemzők nem látnak esélyt belátható időtávban a kapcsolatok számottevő javulására, ugyanakkor számos olyan tényezőt vázolnak fel az elkövetkező néhány évre, amelyek hosszú távra meghatározhatják a viszony stabilitását. Ilyen az INF-szerződés felbontása, illetve annak következményei. Miközben rövid és középtávon a szakértők nem számolnak európai rakétatelepítéssel vagy új fegyverkezési versennyel, hosszú távon komoly problémaként értékelik az átláthatóság hiányát, különösen, ha nem kerül sor az új START-megállapodás aláíására. Az ukrajnai konfliktus helyzetét szintén ilyen tényezőnek tekintik. Úgy vélik, ha rövid távon nem lesznek legalább gesztusértékü lépések a konfliktus megoldásának irányába, akkor jelentősen csökken az esély fontos, a bizalmat erősítő és a feszültséget stabil mederben tartó megállapodások tető alá hozására is.

\section{FELHASZNÁLT IRODALOM}

Barbashin, Anton- Graef, Alexander: Thinking Foreign Policy in Russia: Think Tanks and Grand Narratives, [online], 2019. 11. 12., 7. o. Forrás: Atlantic Council [2019. 10. 24.]

Kobrinskaya, I. - Machavariany, G. (szerk.): IMEMO Forecast - Russia and the World 2019, [online] New Perspectives, 27. évf. 2019/2, 1-29. o. [2019. 10. 24.]OstroukH, Andrey- Golubkova, Katya: Putin stands by China, criticizes U.S., in trade, Huawei disputes, [online], 2019. 06. 07. Forrás: Reuters.com [2019. 10.24.]

History of IMEMO, [online], Forrás: www.imemo.ru [2019. 10. 24.]

Skripal case: US slaps new sanctions on Russia, [online], 2019. 08. 02. Forrás: bbc.com [2019. 10. 24.]

Trenin, Dmitri: Why Putin Isn't Sweating the Midterms, [online], 2018. 11. 06. Forrás: Politico.com [2019. 10. 24.]

U.S. - Russia Crisis Stability: Results from a Strategic Dialogue, [online], 2018. 06. 13. Forrás: csis.org [2019. 10. 24.]

A VCIOM központ honlapja, [online], 2019. 10. 24. Forrás: vciom.ru

Дынкин, А. А. - Барановский, В. Г.: Россия и мир: 2019, [online], 2018. Forrás: imemo.ru [2019. 10. 24.] 